\title{
Penyelidikan Kuat Tekan Komposit Polimer yang Diperkuat Serbuk Kayu Sebagai Bahan Baku Konstruksi Kapal Kayu
}

\author{
Suhardiman, Asroni Mukhlis \\ Jurusan Teknik Mesin Politeknik Negeri Bengkalis \\ E-mail : Suhardiman@polbeng ac.id
}

\begin{abstract}
Abstrak
Pada saat ini, penggunaan bahan baku kayu untuk pembuatan konstruksi kapal kayu sangat terbatas.Sementara hasil serbuk kayu dari olahan mabel tidak dimanfaatkan secara ekonomis. Oleh karena itu perlu perlu dilakukan kajian untuk serbuk kayu menjadi bahan baku alternative pada pembuatan konstriksi kapal kayu. Dalam penelitian ini, digunakan serbuk kayu dengan bahan pengikat polimer resin. Proses dalam pelaksanaan penelitian ini, dengan menvariasikan 4 variabel perbandingan yaiti 1:1, 2:1, 2.5:1 dan 3:1 dengan fraksi volume. Kemudian dibuat spesimen uji tekan sebanyak 5 buah spesimen untuk masing-masing variabel.. Hasil menunjukkan bahwa perbandingan serbuk kayu dengan polimer resin (1:1), mendapat nilai kekuatan tekan $f_{c}=820 \mathrm{~kg} / \mathrm{cm}^{2},(2: 1)$, mendapat nilai kekuatan tekan $f c=620 \mathrm{~kg} / \mathrm{cm}^{2},(2,50: 1)$, mendapat nilai kekuatan tekan $f c=500 \mathrm{~kg} / \mathrm{cm}^{2}$, dan (3:1), mendapat nilai kekuatan tekan $f_{c}=580 \mathrm{kN} / \mathrm{mm}^{2}$.
\end{abstract}

Kata kunci : serbuk kayu, komposit, polimer, kuat tekan

\section{Pendahuluan}

Kayu merupakan bahan baku untuk pembuatan kapal kayu dan mebel, hal ini dikarenakan kayu mudah dibentuk dan mudah mendapatkannya. Pada proses pengolahan tersebut juga menghasilkan serbuk kayu yang tidak sedikit sehingga banyak manusia mengolah serbuk tersebut menjadi bahan baku yang dapat dimanfaatkan kembali.. Dalam hal ini serbuk dari sisa olahan kayu belum dikenal baik oleh masyarakat tentang kegunaannya, sehingga pemanfaatan belum maksimal dan hanya menjadi limbah dilingkungan. Untuk penelitian ini serbuk kayu dari sisa olahan pabrik akan diuji kekuatan dengan menganalisa serbuk kayu dengan matrik polimerr resin sehingga akan didapatkan kekuatan kedalam kelas kayu yaitu I, II, sampai IV. Untuk penggunaan pembuatan kapal kayu diperlukan kelas kayu untuk merencanakan kontruksinya. Misalnya pada keel kapal diperlukan kelas kayu I. Sedangkan pada konstruksi bangunan atas kapal diperlukan kelas kayu II.

Selain itu pemakaian kayu sebagai bahan konstruksi kapal tidak sepesat pemakaian bahan beton atau baja disebabkan oleh Panjang kayu yang terbatas,kekuatan kayu relatif kecil, penampang kayu kecil. mudah terpengaruh oleh zat-zat kimia, peka sekali terhadap kadar air dan sifat kembang-susutnya besar.

Adapun tujuan adalah menyelidiki kekuatan serbuk kayu yang dijadikan bahan komposit yang kemudian dihubungkan dengan penggunaan pada konstruksi kapal kayu.

\subsection{Material Kayu}

Indonesia merupakan suatu negara yang sangat kaya akan bahan kayu baik jenis maupun kuantitasnya, maka pemakaian bahan kayu untuk konstruksi dapat dikembangkan, walaupun pada saat ini manusia lebih menyukai bahan beton atau bahan baja untuk struktur dari suatu bangunan.

Pada Gambar 1 memperlihatkan struktur kayu serta keterangan yang terdapat pada pada Gambar kayu dibawah ini.
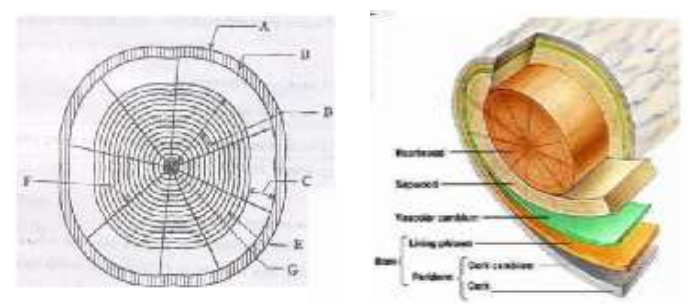

Gambar 1. Gambar Struktur kayu 


\subsection{Sifat mekanis bahan kayu}

Faktor-faktor yang mempengaruhi sifat-sifat mekanis bahan kayu antara lain yaitu : Berat jenis, Kadar lengas, Kecepatan pertumbuhan, Posisi cincin tahun, Mata kayu, Retak-retak, Kemiringan arah serat, Batang pohon kayu mati atau hidup, Pengerinagan kayu alami atau oven, dan Pengawetan Waktu.

Lembaga pusat penyelidikan kehutanan membagi kekuatan kayu Indonesia dalam lima kelas-kuat didasarkan pada jenis kayu yang diteliti sebagai berikut:

Tabel 1.

Kelas kuat jenis kayu

\begin{tabular}{llll}
\multicolumn{4}{c}{ Kelas kuat jenis kayu } \\
$\begin{array}{c}\text { Kelas } \\
\text { kuat }\end{array}$ & Berat jenis & $\begin{array}{c}\text { Kekuatan } \\
\text { lengkung } \\
\text { Absolut } \\
\left(\mathrm{kg} / \mathrm{cm}^{2}\right)\end{array}$ & $\begin{array}{c}\text { Kekuatan } \\
\text { tekan } \\
\text { Absolut } \\
\left(\mathrm{kg} / \mathrm{cm}^{2}\right)\end{array}$ \\
\hline I & $>0.90$ & $>1100$ & $>650$ \\
II & $0.90-0.60$ & $1100-725$ & $650-425$ \\
III & $0.60-0.40$ & $725-500$ & $425-300$ \\
IV & $0.40-0.30$ & $500-360$ & $300-215$ \\
V & $<0.30$ & $<360$ & $<215$ \\
\hline Sumber: Biro Klasifikasi Indonesia $(1989)$ &
\end{tabular}

\subsection{Komposit}

Komposit adalah gabungan dari dua komponen atau lebih yang memberikan sifat kaku. Komposit mempunyai kelebihan akan daya tahan terhadap lingkungan korosif, rasio kekuatan terhadap berat yang tinggi, sifat mekanik, insulasi listrik yang baik serta dapat dibuat dalam berbagai bentuk. Disamping kelebihan, komposit juga memiliki kekurangan sebagai berikut : tidak dapat digunakan pada temperatur $>400^{\circ} \mathrm{F}$, kekakuan tidak terlalutinggi dibandingkan dengan logam dan harga bahan baku yang relatif tinggi. Sedangkan keuntungan dari komposit adalah ringan, kaku dan kuat, maka komposit banyak digunakan dalam aplikasi kehidupan sehari-hari.

\subsection{Pengujian Tekan}

Beberapa pengertian yang berkaitan dengan Metode Pengujian ini :

1. kuat tekan kayu bangunan struktural adalah gaya tekan per satuan luas bidang tekan;

2. kuat tekan sejajar arah serat adalah kekuatan kayu memikul beban yang bekerja padanya yang arah beban sejajar dengan arah serat kayu;

3. kuat tekan tegak lurus arah serat adalah kekuatan kayu memikul beban yang bekerja padanya yang arah bebantegak lurus dengan arah serat kayu;

4. benda uji bebas cacat adalah benda uji kayu yang bebas dari mata kayu, gubal, retak, lubang, jamur, rapuh dan tidak memuntir;
5. Newton adalah satuan menurut Sistem Internasional (SI) untuk gaya ekivalen dengan $0,1 \mathrm{~kg} \int$ dan ditulis dengan notasi $\mathrm{N}$;

6. Mega Pascal adalah 106 pascal ekivalen degan $\mathrm{kgf} / \mathrm{cm} 2$ dan ditulis dengan notasi Mpa;

7. kayu kering udara adalah kayu dengan kadar air maksimal $20 \%$;

8. gubal adalah bagian terluar dari kayu yang berbatasan dengan kulit dan merupakan bagian batang yang masih hidup berisi zat makanan cadangan biasanya berwarna terang.

Benda uji harus memenuhi ketentuan yaitu ukuran benda uji dalam milimeter, seperti Gambar 2;

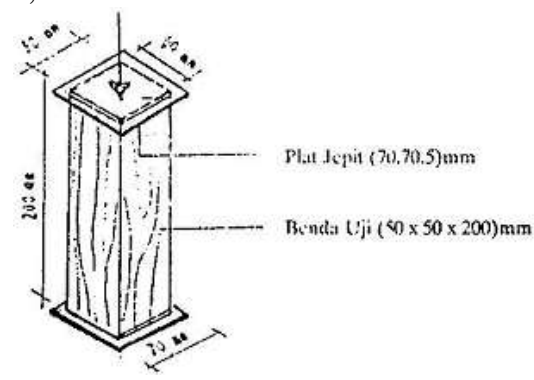

Gambar 2. Contoh Gambar benda uji tekan

\section{Methodologi}

\subsection{Tempat}

Tempat penelitian dilaksanakan Laboratorium Uji Material Program Studi Teknik Mesin Politeknik Negeri Bengkalis dan didasari dengan pengumpulan data yang diambil dari hasil pengujian langsung dilapangan dan mengamati objek yang diteliti serta menganalisanya.

\subsection{Persediaan Bahan}

Adapun bahan utama yang harus dipersiapkan dalam pembuatan spesimen yaitu serbuk kayu dimana pengambilan serbuk kayu dari sisa olahan pabrik mable yang berada di Bengkalis

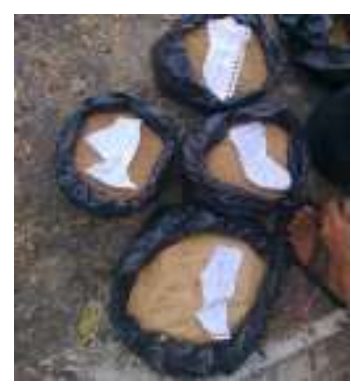

Gambar 3. Serbuk kayu (Sumber: Dokumentasi) 
Untuk pengikat serbuk kayu digunakan resin.

\subsection{Pembuatan Spesimen}

Pembuatan spesimen yang telah direncanakan dengan ketentuan-ketentuan yang telah direncanakan. Pembuatan spesimen uji yaitu berbentuk balok persegi panjang dengan ukuran 50 × 50 × $200 \mathrm{~mm}$ dari hasil cetakan sesuai standar Nasiaonal indonesia (SNI) 033958-1995 sebagai berikut:

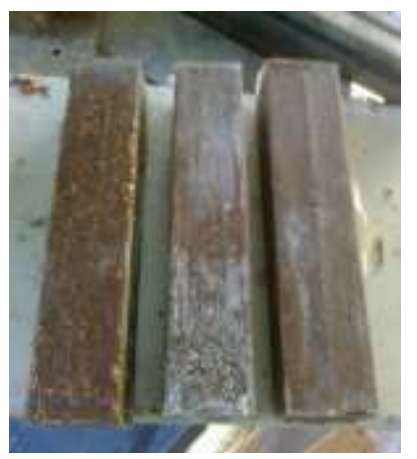

Gambar 4. Spesimen Uji (Sumber: Dokumentasi)

\section{Hasil dan Pembahasan}

\subsection{Komposit Serbu Кауи : Resin $(1: 1)$}

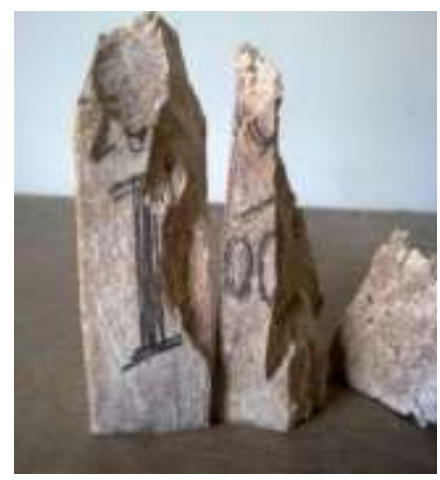

Ganbar 5. Spesimen 1:1 (Sumber: Dokumentasi)

Dari hasil pengujian dapat didevinisikan pada saat melakukan pengujian sampel pertama spesaimen mengalami tekukan pada bagian tengah samping spesimen bertepatan jarum nilai kuat tekan mulai berkisar pada angka dua ratusan pada mesin uji, setelah proses pengujian berlangsung sebelum mencapai batas maksimun, maka spesimen langsung mengalami pecah dari bentuk spesimen awal sebelum dilakukan pengujian.

\subsection{Komposit Serbuk Kayu : Resin $(2: 1)$}

Pada spesimen ini saat dilakukan pengujian tekan, spesimen mengalami perubahan deformasi awal mulai dari berkisarnya jarum skala menunjukkan angka pada seratusan sehingga sampai pada batas maksimum sepesimen uji terjadi tekukan atau bengkok, dan pada bagian tengah samping permukaan spesimen tampak retak atau remuk, seperti pada gambar diatas spesimen yang telah dilakukan pengujian pada gambar 6 dibawah.

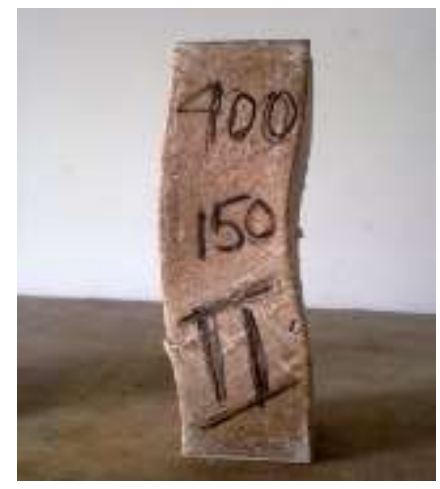

Gambar 6. Spesimen 2:1 (Sumber: Dokumentasi)

\subsection{Komposit Serbuk Kayu : Resin (2.5:1)}

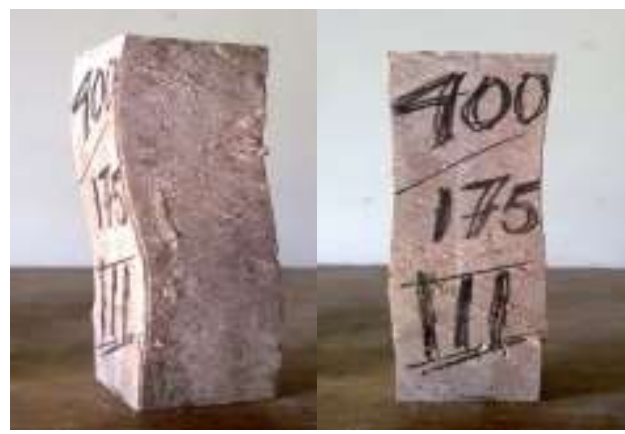

Gambar 7. Spesimen 2.5:1 (Sumber: Dokumentasi)

Pada saat pengujian spesimen sampel ketiga, spesimen uji mengalami deformasi setelah jarum skala mesin uji tekan menunjukan angka ratusan sudah mulai terjadi bengkokan dan berbentuk retak-retak akar pada bagian permukaan samping spesimen sehingga kekuatan tekan sampai kebatas maksimum yang telah ditentukan. Dari hasil pengujian spesimen yang telah diuji dapat dilihat pada gambar 7 diatas.

\subsection{Komposit Serbuk Kayu : Resin (3:1)}

Berdasarkan perlakuan spesimen yang telah dilakukan pengujian uji tekan pada sampel keempat kemampuan kekuatan sampel mengalami pecah pada jarum skala menunjukkan angka $145 \mathrm{kN} / \mathrm{mm}^{2}$. Pada 
spesimen ini dari bentuk pecahnya dapat diuraikan bahwa pada kekuatan beban berkisar antara ratusan pada jarum skala, spesimen mulai terjadi retak dibagian tengah samping semua permukaan spesimen, selama berlangsungnya proses pengujian belum sampai pada beban maksimum spesimen uji langsung mengalami pecah yang tidak beraturan, sehingga dari bentuk pecah pada hasil pengujian sampel keempat tersebut dapat dilihat pada gambar 8 dibawah.

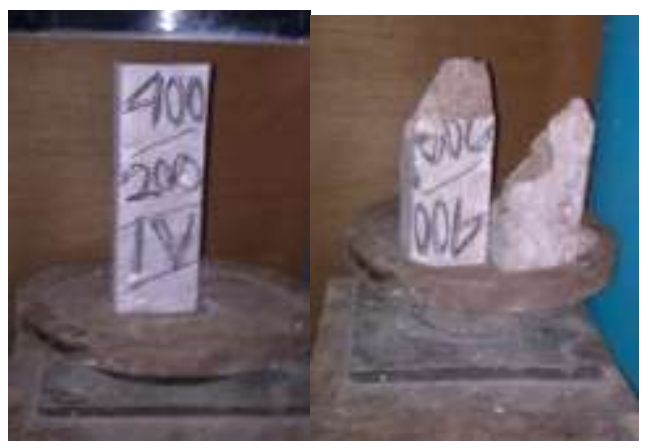

Gambar 8. Spesimen 3:1 (Sumber: Dokumentasi)

Dari perhitungan nilai setiap spesimen yang telah dilakukan pegujian tekan, maka telah dapat perbandingan kekuatan tekan antara empat komposisi tersebut seperti pada tabel dibawah ini:

Tabel 1.

Hasil Kuat Tekan

\begin{tabular}{cccc}
\hline sampel & $\begin{array}{c}\text { Kelas } \\
\text { kuat }\end{array}$ & $\begin{array}{c}\text { Berat jenis } \\
\left(\mathrm{gr} / \mathrm{cm}^{3}\right)\end{array}$ & $\begin{array}{c}\text { Kuat tekan } \\
\text { Absolut } \\
\left(\mathrm{kg} / \mathrm{cm}^{2}\right)\end{array}$ \\
\hline 1 & I & 1,35 & 820 \\
2 & II & 1,33 & 620 \\
3 & II & 1,32 & 500 \\
4 & sII & 1,30 & 580 \\
\hline
\end{tabular}

Berdasarkan nilai kekuatan tekan yang diambil dari perhitungan diatas, maka akan dapat nilai tekan setiap sampel dan dapat disimpulkan bahwa terdapat nilai maksimum dan nilai minimum seperti pada table diatas. Adapun nilai pada kekuatan tekan yang terbesar yaitu spesimen yang campurannya resin dengan serbuk kayu (1:1), dan nilai terbesar kedua yaitu spesimen yang campurannya resin dengan serbuk kayu (2:1), dan nilai terbesar ketiga yaitu spesimen yang campurannya resin dengan serbuk kayu $(2,50: 1)$ dan nilai terkecil dari keempat sampel yaitu spesimen yang campurannya resin dengan gr serbuk kayu (3:1).

\section{Simpulan}

\subsection{Simpulan}

1. Dari hasil pengujian tekan specimen sebanyak 4 variabel penelitian, maka didapat nilai dari masing-masing variabel sebagai berikut: fc $(1: 1)=820$ $\mathrm{kg} / \mathrm{cm}^{2}$, fc $(2: 1)=620 \mathrm{~kg} / \mathrm{cm}^{2}$, untuk, fc $(2.5: 1)=500 \mathrm{~kg} / \mathrm{cm}^{2}$, dan fc $(3: 1)=$ $580 \mathrm{~kg} / \mathrm{cm}^{2}$, untuk spesimen keempat.

2. Dari keempat persentase campuran diatas dapat diambil satu sampel yang mempunyai nilai kekuatan terbesar dan memenuhi setandar yaitu dengan campuran (1:1) antara komposit serbuk kayu dengan polimer resin.

3. Berdasarkan pengujian material, maka telah diketahui nilai maksimum dari material komposit tersebut.

\subsection{Saran}

1. Untuk kesempurnaan hasil pengujian, hendaknya memperhatikan fisik dari mesin uji tersebut, karena fisik mesin kurang sempurna dapat mempengaruhi nilai uji dan gagal uji.

2. Apabila ada yang ingin meneruskan penelitian ini, sebaiknya jumlah spesimen diperbanyak lagi untuk kesempurnaan atau agar lebih akurat dari hasil pengujian ini, serta metode pada persentase campuran serbuk kayu sebagai bahan baku harus diperhatikan dengan membuat sampel sebanyak mungkin untuk dibandingkan mana yang layak digunakan.

3. Laporan tugas akhir ini dapat dikembangkan lagi dengan cara dilakukan pengujian tarik dan pengujian bending.

\section{Daftar Pustaka}

Biro Klasifikasi Indonesia, (1996). “ Peraturan Klasifikasi dan Konstruksi Kapal Kayu”, Surabaya

Dramansyah, (2010).'Evaluasi Sifat Komposit Fiber glass”. Universitas Indonesia, Jakarta.

Hunggurami, E, (2015). "Pengujian Kuat Tekan dan Kuat Lentur Material Pengganti Kayu", Jurnal Teknik Sipil Vol. IV, No.2 Jakarta

Pari, (2002). "Serbuk Gergaji Merupakan Salah Satu Jenis Limbah Industri Pengolahan Kayu Gergajian”, Jurnal Rekayasa Teknik Sipil, Bandung 
Stark, N.M., and Rowlands, R.E.,2002., "Effect of Wood Fiber Characteristic on Mechanical Properties of Wood/Polypropylene Composites., "Wood and Fiber Science., Vol.352003. 